\title{
El soplo de la ciencia me dirige
}

\author{
Para el número 10 de UVSERVA
}

El soplo de la ciencia me dirige, al puerto del progreso tan deseado. El cielo de los datos con su hado, señala mi destino y me rige.

Un lustro se acumula en mis aguas, su hondura me sostiene en la verdad. Al alba se descubre mi bondad, mis sueños se consumen en sus fraguas.

Navego por un mar llamado mundo, estudio por las noches sus estrellas. La luz que se refleja sobre ellas, me lleva a la razón en que me fundo.

Lo nuevo yo lo nombro y lo describo, lo vuelvo un elemento del lenguaje. UVserva traza el curso de mi viaje, su esencia se percibe en lo que escribo

Xalapa, Veracruz, México, 2020

Dr. Juan Ángel Torres Rechy 